\title{
Spatial Relationships of Urban Land Use, Soils and Heavy Metal Concentrations in Lagos Mainland Area
}

\author{
${ }^{1}$ ELIAS, PETER, ${ }^{2}$ GBADEGESIN, ADENIYI \\ ${ }^{1}$ DEPARTMENT OF GEOGRAPHY, UNIVERSITY OF LAGOS, LAGOS \\ Email: po_elias@yahoo.com/pelias@unilag.edu.ng \\ Tel: $234-803-401-0411$ \\ ${ }^{2}$ DEPARTMENT OF LAGOS, UNIVERSITY OF IBADAN, NIGERIA \\ Email: adeniyig@yahoo.com
}

\begin{abstract}
Soils are the basic and most important resources of any people. Differences in soil's physical and chemical properties are related to the spatial distribution of land uses. Most of these human activities generate toxic substances that are transported considerable distances away from source and become accumulated in soils, sediment, water bodies and fisheries. Urban soils are largely affected by impact of urbanization whose consumptive pattern is related to the social and economic aspect of the society. The study deployed contaminant factor (CF) and geo-accumulation index (Igeo) to examine the differences in the urban soils of Lagos Mainland Area due to human activities. The topsoils of the predominant human activities identified in the area were sampled and analyzed to find out the differences in the soils due to the concentration of heavy metals among six land use types. The coefficient of variation and standard deviation techniques were deployed to study the degree of variation and compare the mean values of soil physical and chemical properties of twelve representative topsoils collected from six locations. All metals analyzed showed significant $(\mathrm{p}<0.05)$ variation in the concentration of heavy metals, CF and Igeo among land uses. Spatial distribution of heavy metals indicates areas of potential risks of harmful heavy metals in the urban environment which enhances action plan for remediation and protection of the urban environment. @JASEM
\end{abstract}

Key words: Urban Land use, Soils, Heavy metals, Contamination Factor, Geo-accumulation index

Over the years, Lagos State has become an increasingly urban society. Recent population census has put Lagos among the first ten Mega-Cities of the World. With this current trend, the number of human activities in major Lagos Mainland Areas such as the Lagos Mainland Area has been growing at a phenomenal rate. Different kinds of human activities are distributed within the srea and generate toxic substances in different proportion which are transported considerable distances away from sources and become accumulated in soils, sediment, water bodies and fisheries. The association between urban soils and land use is very crucial as they are related to consumptive pattern of the society. And the fact that the concentration, distribution and sources of these harmful heavy metals in the urban environment have implications for soils, sediment, water and fisheries on the one hand and human life quality on the other makes this study imperative. Voroney (2006) argued that small quantities of these metals are common and necessary in our environment and diet for good health, but large quantities of any of them could result in serious and chronic toxicity. Human land use affects the natural geological and biological redistribution of heavy metals through pollution of the air, water and soil which could lead to heavy metals toxicity by allowing it to bioaccumulate in plants, animals and soils. This bioaccumulation in the food chain has been found to attack specific organs of the body (Goyer, 1996). For instance, Voroney (2006) submitted that bioaccumulation could result in damaged or reduced mental and central nervous function, lower energy levels and damage to blood composition, lung, kidneys, liver and other vital organs. Long term exposure could also result in slowly progressing physical, muscular and neurological degenerative processes that mimic Alzheimer's diseases, Parkinson's disease, muscular dystrophy and multiple sclerosis.

A number of studies on pollution have been conducted depicting the patterns of the major components of pollution in Lagos (Iwugo, K.O, D'Arcy, B., Andoh R., 2003). Most of these studies have focused more on pollution of water bodies and aquatic resources. But hardly have any studies attempted a correlation between human land use and urban soil pollution or mapped areas of potentials risks of urban soil pollution for biodiversity, residents and tourists in the Lagos Mainland Area. Such heavy metals as mercury, arsenic, copper, cyanide, iron, lead, cadmium, chromium, nickel, phenols are found in soils, sediment, water bodies and fisheries of highly urbanized areas (Louella et all, 2006).

There is a relationship between human land use and environmental concentrations of heavy metals in urban soils. This is usually associated with the impact of urbanization on land use pattern (Widinarko et al, 2005).

Urban soil pollution due to environmental concentration of heavy metals in soils and sediments is of great concern. This has brought about high level of awareness of the environmental and human health 
Spatial Relationships of Urban Land Use.....

impact of heavy metal concentrations in urban soils in recent times (Abrahams, 2002; Schroeder et al., 2003; 2004; Mielke et al., 2005; Selinus et al., 2005). All heavy metals are important because they cannot be biodegraded and are largely immobile in the soil system, so they tend to accumulate and persist in urban soils for a long time. This results in levels that are harmful to humans upon both acute and chronic exposure (Thornton, 1991; Brinkmann, 1994; Sheppard, 1998). The most frequently reported heavy metals with regards to potential hazards and the occurrence in contaminated soils are $\mathrm{Cd}, \mathrm{Cr}, \mathrm{Pb}, \mathrm{Zn}$, $\mathrm{Fe}$ and $\mathrm{Cu}$ (Alloway, 1995). The concentration of these heavy metals in soils may be derived from various sources, including anthropogenic pollution, weathering of natural high background rocks and metal deposits (Senesi et al., 1999). Although heavy metals distribution in soils is well documented for many cities of developed countries, comparatively little is known in developing countries (Thuy et al., 2000). Yet, the rate of urbanization and growth of human population and land uses in these countries have continued uncontrolled and unplanned. Thus, a number of human land uses are usually haphazardly sited which introduce harmful chemical substances that could affect humans and the environment negatively. The location of markets, industries, automobile shops, residential areas and traffic networks are found everywhere in Lagos Mainland Area and discharging numerous contaminants to the environment unabated. This necessitates a study of the spatial pattern of urban soil pollution in Lagos Mainland Area to determine areas of potential risks of these harmful heavy metals which could enhance remediation and protection of the urban environment. The objectives of the study were to study the association between land uses and heavy metal concentration, to compare the level of pollution due to anthropogenic activities different from background surface rock accumulation and to deduce their implications for the sustainable management of the Lagos urban environment of the Lagos Mainland Area.

\section{MATERIALS AND METHODS}

\section{Study Area}

Lagos State megacity is located in southwestern Nigeria on the West Coast of Africa. The State is bordered to the north and east by Ogun State, to the west by the Republic of Benin and to the south by the Atlantic Ocean/Gulf of Guinea. The total landmass of the State is about 3,345 square kilometers, which is just about $0.4 \%$ of the total land area of Nigeria. In terms of land mass, it is the smallest of all the states but the most highly populated with an estimated population of about 10 million inhabitants which is about $10 \%$ of the total population of Nigeria (NPC, 2006), Africa's most populous country. The topography of Lagos State generally slopes gently downwards from north to south, and is particularly low lying and flat in the metropolis especially around Victoria Island, Lagos Island/Ikoyi, and Apapa. Lagos consists of two main areas, namely; the Lagos Island and Mainland. The original city and Ikoyi, Victoria Island and Lekki corridor areas are referred to as Lagos Island, while Mainland encompasses the other part of the State (Figure 1). The Mainland part of the State had developed and still developing rapidly and approaching an eventual merger with the more distant part of the Mainland including Ikorodu, Epe and Badagry. A large portion of Lagos Mainland is built on a slightly higher north-south ridge. A considerable part of the State area is made up of Lagoon and creeks. Lagos Mainland Area shares some of the physical and economic characteristics of Lagos State.

Lagos State is naturally made up of depositional landform, which include; wetland, barrier island, beaches, low-lying tidal flats and estuaries. The climate is the wet equatorial type influenced by nearness to the equator and the Gulf of Guinea. There are two main seasons, namely; the rainy season and dry season, which usually lasts from April to October and October to March respectively. The rainy season has two peak periods; May to July and September to October, with rainfall being heaviest during the first peaked period. Floods usually results at these periods, which are aggravated by the poor surface drainages systems of the coastal lowlands. The mean annual rainfall varies from one location to another with areas around the Lagos Mainland including Ebute-metta, Yaba, and Bariga recording $1750 \mathrm{~mm}$, of rainfall compared to Badagry at the extreme west of the State recording $1636.1 \mathrm{~mm}$, Epe at the extreme north-east recording $1676.5 \mathrm{~mm}$ and Agege in the north-west recording $1567.2 \mathrm{~mm}$. Lagos State has a constant high temperature, with mean monthly maximum temperature of about $30^{\circ} \mathrm{C}$. The State experiences the highest temperature around November to December and February to March, while the lowest temperature occurs around June to July which coincides with the middle of the first peak of the rainy season. The humidity level is generally high all over the State throughout the year. 


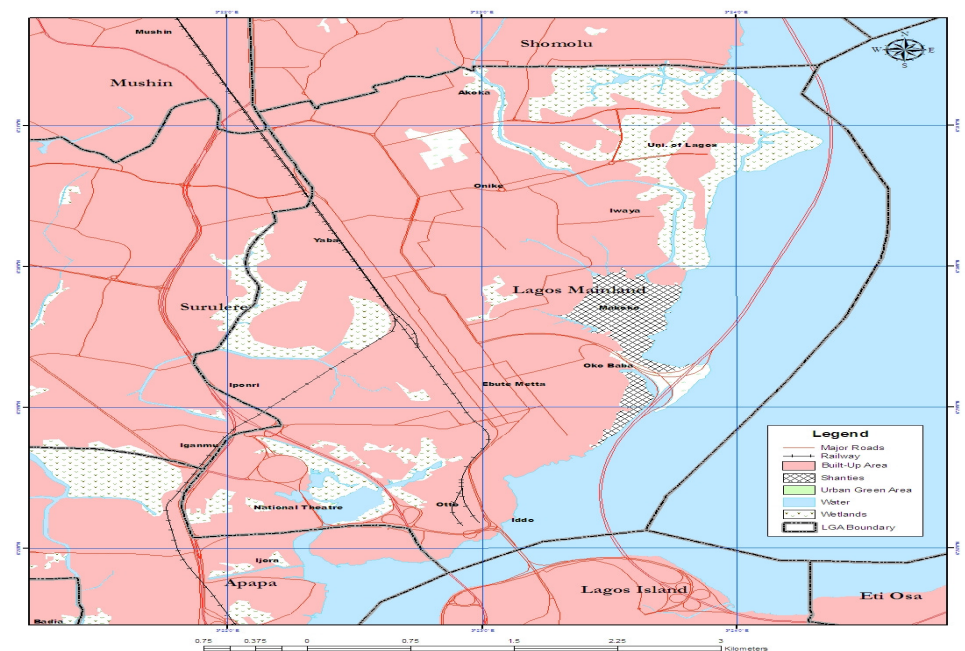

Figure 1: A Land Uses in Lagos Metropolis including Lagos Mainland Area

\section{Sampling Procedure and Preparation}

Extensive reconnaissance land use survey and sampling were carried out in Lagos Mainland Area to identify major human activities that dominate the area. Institutional, commercial, industrial, transport, agricultural and residential land uses were the dominant types found in the area. But with respect to urban soil pollution from heavy metals the survey of the area indicated that industrial, residential, commercial, agricultural and transport land uses were the major contributors to urban soil pollution in Lagos Mainland. Within each land use type, the most extensive and pervasive human activity was selected to represent each land use category from where soil collection was made.

Twelve representative soils/sediments were collected from six locations at a Saw Mill at OkoBaba (31N 0543241, UTM 0717665), A Dumpsite at OkoBaba (3IN 0543243, UTM 0717665), A Market at Sabo (3IN 0541895, UTM 0719300), a Residential Area at Alogomeji (3IN 0542030, UTM 0718701), A Traffic Area at Onike (31N 0542071, UTM 0719240) and A Farm Garden at Folagoro (31N 0542353, UTM 0720903) within Lagos Mainland.

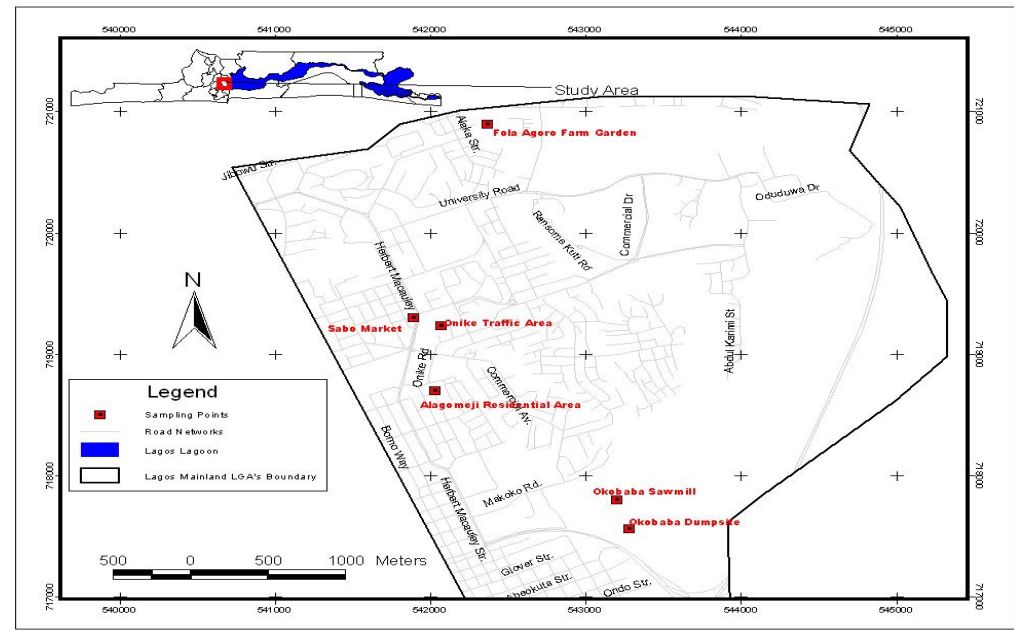

Figure 2: Sampling Locations

For each location both the top soil $(0-15 \mathrm{~cm})$ and subsoil soil $(15-30 \mathrm{~cm})$ samples were collected with a 
Spatial Relationships of Urban Land Use.....

soil auger and transferred in polythene bags for laboratory analysis at the Department of Chemistry Laboratory of the University of Lagos.

Soil physical analysis was done to determine the particle size distribution, soil moisture content and total organic carbon of the sampled soils/sediments. The particle size distribution of the soil samples was determined by wet sieving using sieves of various mesh sizes and gravity sedimentation, in a measure of cylinder. The particle held by each sieve sizes was weighed and expressed as a percentage of overall mass of each soil used in the experiment. The particles were differentiated into sand, gravel, silt and clay according to the mesh size of the sieves. The soil moisture content was determined by drying a known mass of each soil to a constant mass at a temperature of $105^{\circ} \mathrm{c}$ in an oven. The Walkey-Black method was used in the determination of organic carbon content (TOC). This involved a wet combustion (oxidation) of the organic matter in a known mass of samples with a mixture of potassium dichromate sulphuric acid. After the reaction, the residual (excess) potassium dichromate was titrated against standard ferrous solution using ferroin indicator. From the result the TOC was calculated.

\section{Determination of Heavy Metal Concentration}

The chemical analysis was done to determine the concentration of heavy metals $(\mathrm{Cu}, \mathrm{Cd}, \mathrm{Fe}, \mathrm{Pb}$, and $\mathrm{Zn}$ ) in samples of soils/sediments. Each soil sample was air dried in the open laboratory for 72 hours. A known mass $(5.0 \mathrm{~g})$ of the sample was digested using concentrated nitric acid. After the digestion, distilled water was added to the digest, filtered and made up to $100 \mathrm{~cm}^{3}$ mark in the standard flask. The resulting solution was used to determine the constituents of metals according to the procedure for water.

\section{Pollution Load Index}

Many authors prefer to express the metal contamination with respect to average shale to represent the degree of quantification of pollution (Muller 1979; Forstner and Wittmann 1983). Some authors (Baruah et al. 1998) have considered the background value of their area of study to be the geometric mean of concentration at the different sample sites, which is the antilog of the arithmetic average of $\log _{10}$ ( $\log$ to the base 10) of the concentration values. According to them, the geometric mean reduces the importance of a few high values in a sample group and, therefore, is numerically less than the arithmetic mean, making it a useful indicator of background for most geochemical data. Such background value, however, ELIAS, PETER; GBADEGESIN, ADENIYI varies from place to place. As such, this methodology of determining background value has not been considered in the present study. Instead, the world surface rock average (Martin and Meybeck 1979) of individual metal has been taken to be the background following the recent works of some authors (Rath et al. 2005). The level of pollution in the soils/sediments was determined using two parameters viz; Contamination (Enrichment) Factor (EF) and Geo-accumulation Index (Igeo).

The Contamination (Enrichment) Factor was used to assess the level of contamination and the possible anthropogenic impact in soils from the selected land uses. To identify abnormal metal concentration, geochemical normalization of the heavy metals data to a conservative element, such as $\mathrm{Al}, \mathrm{Fe}$, and $\mathrm{Si}$ was employed. Several authors have successfully used iron to normalize heavy metals contaminants (Baptista Neto et al., 2000; Mucha et al., 2003). Thus, iron was also used in this study as a conservative tracer to differentiate natural from anthropogenic components. According to Ergin et al., (1991) and Rubio et al., (2000) the metal enrichment factor $(\mathrm{EF})$ is defined as follows:

$$
E F=\frac{\left(\frac{M}{F e}\right)_{\text {sample }}}{\left(\frac{M}{F e}\right)_{\text {background }}}
$$

Where EF is the enrichment factor, $(\mathrm{M} / \mathrm{Fe})_{\text {sample is }}$ the ratio of metal and $\mathrm{Fe}$ concentration of the sample and $(\mathrm{M} / \mathrm{Fe})$ background is the ratio of metals and $\mathrm{Fe}$ concentration of a background. The background value is that of the world surface rock average (Martin and Meybeck, 1979). The enrichment factor values between 0.5 and 1.5 indicate that the occurrence of the metal is due to natural processes but where EF values records 1.5 or more suggest that it is due to anthropogenic sources (Zhang and Liu, 2002).

Geo-accumulation Index (Igeo) introduced by Muller (1979) for determining the extent of metal accumulation in sediments, has been used by various workers in their studies (Glasby et al. 1988; Bhosale and Sahu 1991; Singh 1999; Rath et al. 2005). $\mathrm{I}_{\text {geo }}$ is mathematically expressed as:

$$
I g e o=\log _{2}\left(\frac{C n}{1.5 B n}\right)
$$

Where, $C_{n}$ is the concentration of element ' $n$ ' and $B_{n}$ is the geochemical background value (world surface 
Spatial Relationships of Urban Land Use.....

rock average given by Martin and Meybeck (1979)). The factor 1.5 is incorporated in the relationship to account for possible variation in background data due to lithologic effect. The geo-accumulation index $\left(\mathrm{I}_{\mathrm{geo}}\right)$ scale consists of 4 classes: (i) unpolluted $(<1.00)$ (ii) minimally polluted (1.00-1.99) (iii) more polluted (2.00-2.99) and (iv) highly polluted (3.00-3.99).

\section{RESULTS AND DISCUSSION}

The influence of the spatial land-use structure on the distributions of heavy metal concentrations was analyzed and discussed. Urbanization has resulted in the concentration of human activities in Lagos Mainland Area. Human activities generate toxic substances like heavy metals. These heavy metals in soils results in urban soil pollution which affect the environment and human health. The concentration of heavy metals, contamination factor and Igeo differ among land uses in Lagos Mainland Area provide an understanding of the level of pollution and the implications for urban soils and sustainable development and management.

Urban Development and Human Activities in Lagos Mainland Area

According to projected population growth studies, it has been found that Lagos State population will reach 25 million inhabitants in the next 10 years (2012), making the city the third largest in the world. Lagos is undoubtedly the commercial nerve-centre of Nigeria (and possibly Africa), with the largest concentration of industries. The State still accounts for more than 70 percent of the nation's industrial and commercial establishments with most of these human activities located within the Lagos Metropolis. The Lagos Mainland Area of the State has developed and still developing rapidly hence it has one of the largest concentrations of human population and activities in the State. Lagos Mainland Area is characterized by high density, slums, inadequate infrastructure, high traffic network, an array of markets and a large number of educational and health institutions.

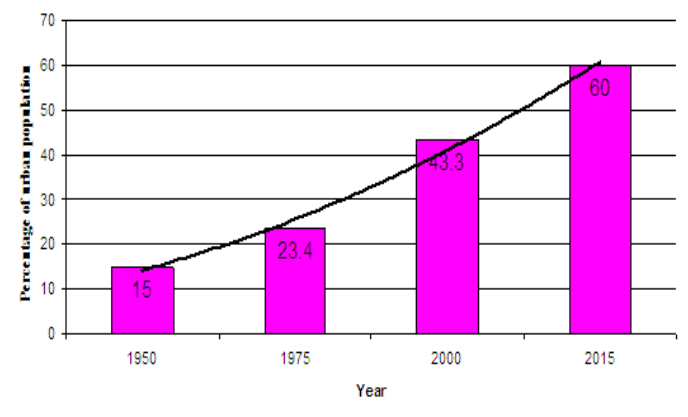

Source: National Bureav of Statistics, Annual Abstract of Stanistics, 2006

\section{Soil Physical Properties in Lagos Mainland}

Soils are the unconsolidated or loose materials on the outermost part of the earth crust. They result from the integrating effects of climate and organism (flora and fauna) on the parent rock materials, conditioned by relief over a period of time. The soil provides support for all components of the environment and serves as the universal sink and filter of all human activities. It is the major component in the relationship between all the various environmental factors which influence land and its capability and suitability for supporting myriad of human land uses.

According to the classification of Moss (1957) and Ojanuga (2006), the soils of the site belong to the group of soils that have developed from saprolites from coastal plain sands. A summary of the soil physical properties are given in Table 1 below. The soils of the studied sites greatly reflect the influence of the prevailing human activities. The soils at the dumpsite were largely organic soils characterized by dark brown colour, which was due to the influence of organic waste. This was corroborated by the amount of soil organic carbon $(48.32 \%)$ content in the composition of the soil. The soils found at the farm garden could be described as clayey soil with brown colour. The high clay $(74.19 \%)$ content in this location may be as a result of the low energy associated with this low-lying coastal environment and perhaps is responsible for the dominance of urban agricultural land use in this area. The soils at the market area can be described as clay sand with dark brown colour. The proportion of clay as earlier mentioned was because of the low-lying terrain accounting for low energy of the transporting agent in the environment. Meanwhile, the dark brown colour is typical of market area where food items are traded. The residential area also had clay sand soil with light brown colour. The mixture of wood waste, soil mineral constituents and water resulted in the muddy soils found in the sawmill area. The highly polluted waste water was accountable for the dark 
Spatial Relationships of Urban Land Use.....

brown colour. The traffic area was typically sandy in nature having no clay and silt in its composition.

Table 1: Physical Properties of Soil/Sediment Samples

\begin{tabular}{|c|c|c|c|c|c|c|c|c|c|c|c|}
\hline \multirow{3}{*}{ Location } & \multirow{3}{*}{\begin{tabular}{|c|} 
Description \\
of Soil
\end{tabular}} & \multicolumn{10}{|c|}{ Soil Physical Properties } \\
\hline & & \multicolumn{5}{|c|}{ Topsoil } & \multicolumn{5}{|c|}{ Subsoil } \\
\hline & & $\begin{array}{l}\text { Sand } \\
\%\end{array}$ & Clay \% & Silt \% & TOC & SM & $\begin{array}{l}\text { Sand } \\
\%\end{array}$ & Clay \% & Silt \% & TOC & SM \\
\hline Dumpsite & \begin{tabular}{|l|} 
Dark \\
Brown \\
Organic \\
Soil
\end{tabular} & 7.15 & - & - & 48.32 & 19.82 & 6.94 & - & - & 49.05 & 20.31 \\
\hline Garden & $\begin{array}{l}\text { Brown } \\
\text { Clayey } \\
\text { Sand }\end{array}$ & 1.37 & 74.19 & 3.25 & 4.16 & 11.71 & 1.02 & 80.2 & 2.19 & 2.34 & 8.86 \\
\hline $\begin{array}{l}\text { Market } \\
\text { Area }\end{array}$ & $\begin{array}{l}\text { Dark } \\
\text { Brown } \\
\text { Clayey } \\
\text { Sand } \\
\end{array}$ & 20.5 & 45.33 & 11.31 & 2.56 & 9.26 & 66.32 & 3.16 & 2.65 & 7.29 & 11.84 \\
\hline $\begin{array}{l}\text { Residential } \\
\text { Area }\end{array}$ & \begin{tabular}{|l} 
Light \\
Brown \\
Sandy Clay
\end{tabular} & 27.42 & 42.19 & 12.39 & 1.24 & 8.55 & 58.11 & 17.42 & 8.26 & 2.86 & 13.74 \\
\hline Sawmill & \begin{tabular}{|l|} 
Dark \\
Brown \\
Muddy Soil
\end{tabular} & 1.28 & 5.19 & 2.41 & 62.15 & 11.65 & 0.45 & 10.26 & 3.56 & 68.29 & 8.37 \\
\hline $\begin{array}{l}\text { Traffic } \\
\text { Area }\end{array}$ & $\begin{array}{l}\text { Brown } \\
\text { Sandy Soil }\end{array}$ & 83.14 & & & 2.37 & 13.29 & 83.19 & & & 2.14 & 13.42 \\
\hline Mean & & 23.48 & 27.82 & 4.89 & 20.13 & 12.38 & 36.01 & 18.51 & 2.78 & 21.99 & 13.42 \\
\hline S.D & & 31.09 & 30.74 & 5.55 & 27.55 & 4.04 & 37.33 & 30.74 & 3.05 & 29.11 & 32.63 \\
\hline C.V \% & & 132.41 & 110.49 & 113.69 & 136.86 & 4.47 & 103.67 & 167.31 & 109.71 & 132.38 & 33.3 \\
\hline
\end{tabular}

The analysis of the concentration of heavy metals (Table 2) indicate that all metals analyzed were found in the topsoil and subsoil of the dumpsite, sawmill and traffic areas while $\mathrm{Cu}, \mathrm{Cd}, \mathrm{Fe}$ and $\mathrm{Zn}$ were found at the market area, $\mathrm{Cu}, \mathrm{Fe}$ and $\mathrm{Zn}$ were found at the farm garden; and only $\mathrm{Cd}$ and $\mathrm{Pb}$ were found at the residential area. The analysis further showed that the metal with the highest topsoil and subsoil concentrations at the dumpsite was $\mathrm{Zn}$ followed by $\mathrm{Fe}$ and $\mathrm{Cu}$ while $\mathrm{Cd}$ had the least. All the identified metals showed only very negligible amount in the topsoil and subsoil of the farm garden area with $\mathrm{Cd}$ and $\mathrm{Pb}$ not detected. $\mathrm{Zn}$ had the highest concentration at the market area followed by Fe; others showed negligible concentration while $\mathrm{Pb}$ was not detected. The topsoil and subsoil of the residential area showed very negligible concentration of all heavy metals except $\mathrm{Cd}$ that was not detected. At the sawmill area, the concentration of all the heavy metals was very negligible. The concentration of heavy metals in the topsoil and subsoil of the traffic area was generally negligible except for $\mathrm{Zn}$. The analysis of the mean values of all the heavy metals showed that $\mathrm{Zn}$ had the highest followed by $\mathrm{Fe}$ and $\mathrm{Cu}$. Again, $\mathrm{Zn}$ had the highest standard deviation followed by $\mathrm{Fe}$ and $\mathrm{Cu}$ whereas $\mathrm{Pb}$ had the highest covariance followed by $\mathrm{Cu}, \mathrm{Fe}$ and $\mathrm{Zn}$ in that order.

Table 2: Concentration of Heavy Metals in Soil/Sediment Samples. TS = topsoil; SS = subsoil; WSR = world surface rock background

\begin{tabular}{|c|c|c|c|c|c|c|c|c|c|c|c|}
\hline $\begin{array}{c}\text { Heavy } \\
\text { metal }\end{array}$ & Horizon & Dumpsite & Garden & Market & Residential & Sawmill & Traffic & Mean & S.D & C.V (\%) & \multirow[b]{3}{*}{32} \\
\hline \multirow[b]{2}{*}{$\begin{array}{l}\mathrm{Cu} \\
(\mathrm{mg} / \mathrm{kg})\end{array}$} & $\mathrm{TS}$ & 12.114 & 0.053 & 0.092 & 0.004 & 0.24 & 0.036 & 2.09 & 4.91 & 234.9 & \\
\hline & SS & 12.825 & 0.037 & 0.087 & 0.01 & 0.292 & 0.031 & 2.21 & 5.19 & 234.8 & \\
\hline \multirow{2}{*}{$\begin{array}{l}\mathrm{Cd} \\
(\mathrm{mg} / \mathrm{kg})\end{array}$} & $\mathrm{TS}$ & 0.008 & ND & 0.014 & ND & 0.021 & 0.005 & 0.008 & 0.0083 & 103.8 & \multirow{2}{*}{0.07} \\
\hline & SS & 0.009 & ND & 0.01 & ND & 0.036 & 0.005 & 0.01 & 0.013 & 130 & \\
\hline \multirow{2}{*}{$\begin{array}{l}\mathrm{Fe} \\
(\mathrm{mg} / \mathrm{kg})\end{array}$} & $\mathrm{TS}$ & 24.056 & 0.021 & 0.282 & 0.007 & 0.29 & 0.657 & 4.22 & 9.72 & 230.3 & \multirow{2}{*}{3.59} \\
\hline & SS & 24.22 & 0.025 & 0.249 & 0.011 & 0.322 & 0.64 & 4.24 & 9.79 & 230.9 & \\
\hline \multirow{2}{*}{$\begin{array}{l}\mathrm{Pb} \\
(\mathrm{mg} / \mathrm{kg})\end{array}$} & TS & 0.26 & ND & ND & ND & 0.002 & 0.007 & 0.045 & 0.11 & 244.4 & \multirow{2}{*}{20} \\
\hline & $\mathrm{SS}$ & 0.252 & ND & ND & ND & 0.005 & 0.009 & 0.044 & 0.102 & 231.8 & \\
\hline \multirow{2}{*}{$\begin{array}{l}\mathrm{Zn} \\
(\mathrm{mg} / \mathrm{kg})\end{array}$} & TSl & 40.354 & 0.083 & 0.634 & 0.025 & 0.756 & 2.41 & 7.38 & 16.18 & 219.2 & \multirow{2}{*}{129} \\
\hline & SS & 40.426 & 0.051 & 0.418 & 0.06 & 0.82 & 2.384 & 7.34 & 16.22 & 220.9 & \\
\hline
\end{tabular}

If compared to global average of heavy metal concentrations in urban soils, the mean values of the analyzed soils are significantly lower than those ELIAS, PETER; GBADEGESIN, ADENIYI reported by studies of large and industrialized cities such as Palermo (Sisily) $202 \mathrm{mg} / \mathrm{kg}$ (Manta et al., 2002), Central London $647 \mathrm{mg} / \mathrm{kg}$ (Rundle and 
Spatial Relationships of Urban Land Use.....

Duggan, 1980), and Rome $330.8 \mathrm{mg} / \mathrm{kg}$ (Angelone et al. (1995). However, the results showed lower values of standard deviations indicating relatively homogeneous distribution patterns of the analyzed heavy metals in all the identified land uses. It can be said that some of these metals had major inputs from natural sources.

The results of the Contamination Factor and GeoAccumulation Index (Tables 3 and 4) indicate that the dumpsite was unpolluted to minimally polluted in $\mathrm{Cu}$, unpolluted in $\mathrm{Pb}$, minimally polluted in $\mathrm{Zn}$, and moderately polluted in Fe. The Farm garden was unpolluted to minimally polluted in $\mathrm{Cu}$ and $\mathrm{Zn}$ and slightly polluted in Fe. The Market area was minimally to highly polluted in $\mathrm{Cu}$, moderately polluted in $\mathrm{Cd}$, minimally polluted in $\mathrm{Zn}$ and slightly polluted in Fe. The Residential area was minimally polluted in $\mathrm{Cu}$, minimally to highly polluted in $\mathrm{Zn}$ and highly polluted in Fe. The Saw mill area was minimally polluted in $\mathrm{Cu}$, highly polluted in $\mathrm{Cd}$, minimally polluted in $\mathrm{Zn}$, and slightly polluted in $\mathrm{Fe}$. The Traffic area was unpolluted in $\mathrm{Cu}$, minimally polluted in $\mathrm{Cd}$, unpolluted in $\mathrm{Pb}$, minimally polluted in $\mathrm{Zn}$ and slightly polluted in $\mathrm{Fe}$.

Table 3: Contamination Factor of Heavy Metals of Soil/sediment Samples

\begin{tabular}{|l|l|l|l|l|}
\hline Location & $\mathrm{Zn}$ & $\mathrm{Cu}$ & $\mathrm{Cd}$ & $\mathrm{Pb}$ \\
\hline Dumpsite & .046 & .056 & .169 & .002 \\
\hline Farm Garden & .110 & .283 & $\mathrm{ND}$ & $\mathrm{ND}$ \\
\hline Market Area & .062 & .037 & 2.546 & $\mathrm{ND}$ \\
\hline $\begin{array}{l}\text { Residential } \\
\text { Area }\end{array}$ & .010 & .064 & $\mathrm{ND}$ & $\mathrm{ND}$ \\
\hline Saw Mill & .073 & .093 & 3.714 & .001 \\
\hline Traffic Area & .006 & .001 & .39 & .002 \\
\hline
\end{tabular}

Table 4: Geo-accumulation Index for Soil/sediment Sample

\begin{tabular}{|l|l|l|l|l|l|}
\hline Location & $\mathrm{Fe}$ & $\mathrm{Zn}$ & $\mathrm{Cu}$ & $\mathrm{Cd}$ & $\mathrm{Pb}$ \\
\hline Dumpsite & 1.345 & 0.063 & 0.076 & .023 & .003 \\
\hline Farm Garden & .001 & -1.29 & -3.23 & $\mathrm{ND}$ & $\mathrm{ND}$ \\
\hline Market & 0.016 & -9.8 & 5.769 & .040 & $\mathrm{ND}$ \\
\hline $\begin{array}{l}\text { Residential } \\
\text { Area }\end{array}$ & 3.913 & 3.889 & -2.5 & $\mathrm{ND}$ & $\mathrm{ND}$ \\
\hline Saw mill & .016 & .001 & .001 & .060 & -2.01 \\
\hline Traffic Area & .037 & .004 & .000 & .014 & -7.023 \\
\hline
\end{tabular}

The study has shown that heavy metal concentration in Lagos Mainland Area was largely the result of natural sources rather than anthropogenic factors. All the land uses identified for the study were loaded with diverse proportions of pollutants due to the prevailing human activities. The prevalence of $\mathrm{Zn}$ in the study area is indicative of the significance of zinc in the ecosystems. The fact that the dumpsite, saw mill and traffic areas reported the concentration of all the heavy metals suggest that these areas need serious monitoring despite the fact that they had low concentration compared to global average. Location of human activities must therefore be done in such a way as to ensure compatibility of land uses. The close proximity of these areas to dense human population is of great concern. Already, the saw mill area has been identified for relocation to a more secluded area at the outskirt of Lagos.

In the same vein, the study of the types and chemical constituents of waste generated from these land uses must be taken seriously for better management. More pragmatic efforts will be required to monitor pollution associated with vehicular traffic. While, it may be argued that these pollutants may have originated from other sources it is sufficient to observe that these indices are enough warnings to alert government agencies to initiate monitoring of urban soils as important components of the urban environment. The other land uses should also be put under close surveillance to ensure that they do exceed the tolerable level in the environment.

\section{Conclusion}

The study sought to examine the associations between land uses and heavy metal concentration in urban land uses, to distinguish heavy metal concentrations resulting from anthropogenic activities different from background surface rock accumulation and to suggest the implications for the sustainable management of the Lagos urban environment of the Lagos Mainland Area. Urbanization has resulted in the concentration of human activities in the Lagos Mainland Area. All the identified land uses generate varying proportions of heavy metals thus confirming the influence of anthropogenic factor. The concentration of heavy metals, contamination factor and Geo-accumulation index differ among land uses. Although majority of the land uses reported unpolluted to minimal pollution indices, their long term bioaccumulation could result in significant impacts, which is of concern in the study area especially in the market area, saw mill area, and residential areas where pollution in $\mathrm{Cu}, \mathrm{Zn}$ and $\mathrm{Cd}$ respectively were reportedly high. Proper allocation, monitoring and management of land uses within urban areas could promote the health of the urban soils and the ecosystems. Planners and policy would need the 
Spatial Relationships of Urban Land Use.....

report from this kind of study to justify and/or authenticate their actions.

\section{REFERNCES}

Abrahams, P.W., (2002) Soils: Their implications to human health. The Science of the Total Environ. 291, 1-32.

Alloway, J. B., (1995). "Soil Pollution and Land Contamination", in Pollution: Causes, Effects and Control, ed. R. M. Harrison.

Angelone M., Corrado, T., and Dowgiallo G., (1995). Lead and cadmium distribution in urban soil and plants in the city of Rome: a preliminary study. Proceedings of the Third International Conference on the Biogeochemistry of Trace Elements. 23 24.

Atayese, M.O., Eigbadon, A.I., Oluwa, K.A., \& Adesodun, J.K. (2008) Heavy metal contamination of Amaranthus Grown Along the Major Highways in Lagos, Nigeria. African Journal of Crop Science, vol., 16, No. 4, pp 225235

Baptista Neto, J.A., Smith, B.J., and McAllister, J.J., (2000). Heavy metal concentrations in surface sediments in a near shore environment, Jurujuba Sound, Southeast Brazil. Environ. Pollut. 109, 19.

Brinkmann, R., (1994). Lead pollution in soils adjacent to homes in Tampa, Florida. Environ. Geochem and Health 16 (2), 59-64.

Ergin, M., Saydam, C., Basturk, O., Erdem, E., Yoruk, R., (1991). Heavy metal concentrations in surface sediments from the two coastal inlets (Golden Horn Estuary and Izmit Bay) of the northeastern Sea of Marmara. Chem. Geo. 91, 269-285.

Federal Republic of Nigeria (2006) Nigerian Population Census National Population Commission

Forstner, U and Wittmann, G.T.W. (1983). Metal pollution in the aquatic environment. SpringerVerlag, Berlin, pp. 30-61.

Iwugo, K.O, D’Arcy, B., Andoh R. (2003) Aspects of Land-Based Pollution of an African Coastal
Megacity of Lagos. A Poster Presented at the Diffuse Pollution Conference, Dublin 2003.

Louella F. Ona, Annie Melinda P. Alberto, Jacqueline A. Prudente and Gilbert C. Sigua (2006) Levels of Lead in Urban Soils from Selected Cities in a Central Region of the Philippines. Environmental Science and Pollution Research, 13 (3) 177-183

Manta, D. S., Angeloneb, M., Bellanca, A., Neri, R., and Sprovieri, M.(2002). Heavy metals in urban soils: a case study from the city of Palermo (Sicily), Italy. The Sci. of the total Environ. 300, 229-243.

Martin, J.M. and Maybeck, M. (1979) Elemental mass of material balance carried by major world rivers, Marine Chemistry, vol. 7, pp 173-206.

Mielke H.W., Berry K.J., Mielke P.W., Powell E.T. and Gonzales C.R. (2005). Multiple metal accumulations as a factor in learning achievement within various New Orleans elementary school communities. Environ. Research 97, 67-75.

Moss, R.P. (1957). Classification of Soils found Over Sedimentary Rocks in Western Nigeria. Soil Survey Report No. 67. MANR, Ibadan, Nigeria, $87 \mathrm{pp}$

Muller, G., (1969). Index of geoaccumulation in sediments of the Rhine River. Geol. J. 2, 109-118.

Mucha, A.P., Vasconcelos, M.T.S.D., Bordalo, A.A. (2003). Macrobenthic community in the Doura estuary: relations with trace metals and natural sediment characteristics. Environ. Pollut. 121, 169- 180

Ojanuga A.G. (2006) Agroecological Zones of Nigeria manual. F. Berding and V.O. Chude (Eds.). FAO and FMA \& RD., 124 pp.

Rubio, B., Nombela, M. A., and Vilas, F., (2000). Geochemistry of major and trace elements in sediments of the Ria de Vigo (NW Spain) an assessment of metal pollution, Marine Pollution Bulletin, 40(11), 968-980

Rundle, S. and Duggan, M (1980) The concentration of lead and other heavy metals in dust from school playgrounds. A Report to Greater London Council, Scientific Branch, Environmental Sciences Division, 14 pp 
Spatial Relationships of Urban Land Use.....

Voroney, R. P.(2006). The Soil Habitat in Soil Microbiology. Ecology and Biochemistry, Eldor A. Paul Edition.

Schroeder, J.L., Basta, N.T., Si, J., Casteel, S.W., Evans, T. and Payton, M., (2003). In vitro gastrointestinal method to estimate relative bioavailable cadmium incontaminated soil. Environmental Science and Technology 37, 13651370.

Schroeder, J.L., Basta, N.T., Casteel, S.W, Evans, T., Payton, T.J. and Si, J., (2004). Validation of the in vitro intestinal (IVG) method to estimate relative bioavailable lead in contaminated soils. Journal of Environmental Quality 33, 513-521.

Selinus, O., Alloway, B., Centeno, J.A., Finkelman, R.B., Fuge, R., Lindh, U. and Smedley, P., (2005). Essentials of Medical Geology, impacts of the natural environment on public Health 144, 890-891.

Senesi, G.S., Baldassarre, G., Senesi, N., Radina, B., (1999). Trace element inputs by anthropogenic activities and implications for human health. Chemosphere 39, 343- 377.

Sheppard, S.C., (1998). Geophagy: Who eats soil and where do possible contaminants go? Environ. Geology 33, 109-114.

Thuy, H.T.T., Tobschall, H.J., and An, P.V., (2000). Distribution of heavy metals in urban soils - a case study of Danang-Hoian Area (Vietnam). Environl. Geology 39 (6), 603-610

Thornton, I., (1991). Metal contamination in urban areas. In: Bullock, P. (Ed), Soils in the Urban Environment; Cambridge University Press, UK. 47-75.

Zhang, J. and Liu, C.L., (2002). Riverine composition and estuarine geochemistry of particulate metals in China - Weathering features, anthropogenic impact and chemical fluxes. Estuar. Coast. Shelf S. 54, 1051-1070. 